Atouts et outils de l'ethnologie des techniques

\title{
Variantes et variations
}

\section{(2) OpenEdition \\ 1 Journals}

Édition électronique

URL : https://journals.openedition.org/tc/629

DOI : $10.4000 /$ tc. 629

ISSN : 1952-420X

Éditeur

Éditions de l'EHESS

\section{Édition imprimée}

Date de publication : 1 septembre 1994

ISSN : 0248-6016

Référence électronique

"Variantes et variations », Techniques \& Culture [En ligne], 21 | 1994, mis en ligne le 30 décembre 2005, consulté le 29 septembre 2022. URL : http://journals.openedition.org/tc/629 ; DOI : https://doi.org/

$10.4000 /$ tc. 629

Ce document a été généré automatiquement le 29 septembre 2022.

Tous droits réservés 


\section{Variantes et variations}

